\title{
Are Tax Avoidance, Corporate Social Responsibility and Financial Performance Affecting Firm Value in the Egyptian Listed Companies?
}

\author{
Dr. Mohamed Hassan Abd-Elmageed, PhD \\ Assistant Accounting Professor \\ Faculty of Commerce - Ain Shams University \\ dr.mohamedabdelmageed@bus.asu.edu.eg
}

Bassant Abdelmordy Mohamed Abo Ashour

Assistant Accounting Lecturer

Faculty of Business - Ain Shams University

bassantmordy@bus.asu.edu.eg 


\section{$\underline{\text { Abstract }}$}

Although previous studies have examined the relationship between tax avoidance and corporate social responsibility, there is no evidence for this relationship in emerging economies, including Egypt that characterized by a weak institutional, enforcement systems and investor protection and a high level of corruption. Therefore, this research examines the relationship between tax avoidance and the level of corporate social responsibility disclosure and show how both have an impact on the firm value.

The topic of this research is rarely investigated in the academic and business literature which is whether the level of tax avoidance influences corporate social responsibility and in turn firm value. Using a research sample of 36 non-financial listed firms during the period 2012-2018, the researcher run six multiple regression models to examine the impact of tax avoidance and corporate social responsibility, Tobin's $\mathrm{Q}$ ratio and firm size on firm value using the financial performance as a moderator variable (measured using margin, current ratio, asset turnover, inventory turnover, profit gross margin, ROE, ROA). The statistical results found that gross profit margin, return on assets and Tobin's $Q$ ratio have a positive significant impact on tax avoidance, while current ratio, asset turnover, inventory turnover, return on equity and firm size have a significant negative relationship with tax avoidance. In addition findings shows that current ratio and return on equity have a positive significant impact on corporate social responsibility, while asset turnover, return on assets, Tobin's Q ratio and firm size have a significant negative relationship with corporate social responsibility. Moreover, tax avoidance, corporate responsibility social, Tobin's Q ratio and firm size found to have a positive significant impact on firm value.

While corporate tax policy is generally considered separate from corporate social responsibility policy, tax evasion has greatly affected the social agenda of the company and in turns its value. Results indicate that companies involved in tax avoidance strategies are likely to increase corporate social responsibility disclosures. These results are consistent with the legitimacy theory that companies increase ESG disclosures to alleviate community concerns about low tax payments and build legitimacy.

\section{Keywords: Tax Avoidance - Corporate Social Responsibility - Financial Performance - Firm Value - Egypt}




\section{Introduction}

Corporate tax avoidance is conventionally viewed as a tax-reducing device that transmits interest from the government to shareholders in order to maximize shareholders' value, although an expanding body of work on agency theory assures that tax avoidance is closely linked to corporate governance because of the agency cost implications. In practice, the complexity and ambiguity of tax avoidance can protect managers who engage in different forms of managerial rent extraction such as earnings manipulation and insider transactions which would decrease after-tax cash flows (Desai and Dharmapala, 2009). Enron's case is a remarkable example. In the 1990s, Enron utilized structured financing transactions to evade tax, leading to government prosecution and its collapse. Beyond that, firms also want to shoulder the combined tax avoidance costs, which include direct tax planning, compliance and non-tax costs. (Lee et al., 2015) proposed that if shareholders can't fully understand the cost-benefit calculus, tax avoidance activities could actually minimize firm value.

Tax avoidance provides many economic benefits to the firm. By decreasing corporate income, the management of the firm is trying to reduce the tax burden that is deposited as expected by shareholders (Armstrong et al., 2015). Tax planning activities have significantly caught the interest of economists, regulators, accountants, researchers, market analysts, and the investment community about tax avoidance activities. However, the adoption of tax planning practices is a debatable issue (Santa, 2016). Meanwhile the tax avoidance strategy is also one of the essential managerial decisions determined by managers (Yee et al, 2018).

Corporate social responsibility is a response to social pressures, in relation to the demands and expectations of stakeholders, environmental concerns, and social demands that characterize the dimensions of corporate social responsibility. These are the most common dimensions of corporate social responsibility that are explicitly mentioned in the definitions of corporate social responsibility. For example, the stakeholder dimension relates to how a company interacts with its employees, suppliers and customers. The environmental dimension refers to how business operations are concerned about the natural environment. The social dimension of corporate social responsibility relates to how the organization contributes to a better society by integrating its business with social interests (Vicente Lima et al, 2011).

Some important corporate social responsibility aspects have been a subject of research, such as its perception, disclosure, and the potential relationship between 
corporate social responsibility and firm performance. Corporate Social Responsibility (CSR) issue relates to a broad spectrum with the relationships between a company and multiple stakeholders, as well as to the environment. Firm relations with many stakeholders, customers, society in general, and even with shareholders, are part of the corporate social responsibility domain.

The most widely used definition of corporate social responsibility is the one proposed in 2001 by Commission of the European Communities which states that corporate social responsibility is "A concept whereby companies incorporate social and environmental concerns into their business operations and in their interactions with stakeholders on a voluntary basis" (Dahlsrud , 2008).

The topic of research is rarely investigated in the business literature which is whether the corporate social responsibility performance influences the level of tax avoidance (Roman Lanis and Grant Richardson, 2015). While corporate tax policy is generally considered separate from corporate social responsibility policy, tax evasion has greatly affected the social agenda around the world, particularly in the post-global financial crisis environment (Duhigg and Kocieniewski, 2012). Tax evasion would be considered by many to be socially irresponsible (Hasseldine and Morris, 2013). Thus, we expect socially responsible companies to be less tax evasion because we view the corporation as a "real world" entity where CSR is a legitimate business activity and not just a cost on the road to maximizing shareholder wealth. Our expectations also align with Porter's view (Porter and Kramer, 2006) as follows:

The interdependence of businesses and society means that business decisions and social policies must follow the principle of shared value. That is, the options should benefit both sides. If a company or community pursues policies that benefit its interests at the expense of another, it will find itself on a dangerous path. One's temporary gain will undermine the long-term prosperity of both.

\section{$\underline{\text { Research Aim and Questions }}$}

The main aim of this research is to how tax avoidance, corporate social responsibility and financial performance effects firm value in the Egyptian listed companies.

1. What is the impact of financial performance on tax avoidance?

2. What is the impact of financial performance on corporate social responsibility?

3. What is the impact of tax avoidance on firm value? 
4. What is the impact of corporate social responsibility on firm value?

5. What is the impact of financial performance on firm value?

6. What is the impact of tax avoidance on corporate social responsibility?

\section{Literature Review and Hypotheses Development}

\section{Tax Avoidance and Financial Performance}

Tax avoidance is broadly known as the reduction in a firm's explicit tax liabilities (Dyreng et al., 2008). Under this broad definition, tax avoidance represents a continuum of tax planning strategies where perfectly legal activities are at one end and more aggressive activities would be closer to the other end (Hanlon and Heitzman, 2010). Tax Avoidance is an engineering of "tax affairs" which is still within the framework of taxation provisions. In General taxpayers attempt to pay taxes as small as possible, because paying taxes means decreasing the economic ability of taxpayers. Tax avoidance, in the positive sense, can be interpreted as a planning action in the fulfillment of complete, correct, and timely tax obligations so as to avoid waste of resources. Tax avoidance, in the negative sense, depicts actions to reduce tax liabilities by utilizing loopholes or shortcomings in the tax regulations.

Financial performance can be seen through various financial ratios, such as profitability ratio and leverage ratio. (Handayani, 2020) utilized return on total assets, current ratio and debt to equity ratio to measure financial performance. Return on total assets is a ratio that demonstrates the results (return) of the total assets used in the company. Current ratio is the ratio to measure the capability of a company to pay short-term liabilities or debt that are due immediately when billed as a whole. The study conducted by (Wiratmoko, 2018) tested the influence of corporate governance, corporate social responsibility, and financial performance on tax avoidance. The study utilized tax avoidance as the dependent variable measured by Cash Effective Tax Rate (CETR), while commissioners, audit committee, corporate social responsibility (CSR), debt ratio, and Return on Assets (ROA) as the independent variables. This study also utilizes firm size as the control variable. The findings of this research indicate that ROA have significant effect on tax avoidance.

\section{Based on the previous illustrated literature, the author formed the following hypothesis:}

\section{$\mathrm{H}_{1}$ : Financial performance has significant impact on tax avoidance.}




\section{Corporate Social Responsibility and Financial Performance}

Corporate social responsibility according to (Kusumadilaga, 2010) is a mechanism for an organization that voluntarily integrates social and environmental concerns into its operations and interaction with stakeholders, which goes beyond the organization's responsibility in the field of law.

In accordance with the international standard ISO 26000 in (Resturiyani , 2012), corporate social responsibility is the responsibility of a firm for the effects of decisions and activities on society and the environment at the conference that is achieved in the form of transparent and ethical behavior consistent with sustainable development and the public good, taking into account the expectations of stakeholders, in accordance with applicable laws and standards of international behavior, integrated with the organization as a whole.

Financial performance is a proxy for the company's ability to utilize its assets from its most important operations to achieve returns. It is the degree to which the set goal has been accomplished or achieved. Financial performance is a reflection of the company's long-term well-being and existence.

Previous research has revealed that implementing corporate social responsibility (CSR) is believed to improve financial performance. Results of the research conducted by (Bidhari et al., 2013) showed that corporate social responsibility disclosure affecting financial performance is return on assets (ROA), return on equity (ROE) and net profit margin (NPM). But there are also studies that show that there is no positive relationship between corporate social responsibility and financial performance. Research by (Yaparto et al., 2013) shows that corporate social responsibility does not have a significant impact on return on assets, return on equity and earnings per share (EPS).

(Lin et al., 2019) argued that one of the primary reasons why corporate social responsibility adds value to a company's performance in the market is the CSR screening process. A strong CSR company may get higher screening scores and become safer when exposed to financial crises or environmental difficulties. Several studies show that the intensity of corporate social responsibility screening has a significant impact on financial performance.

(Novrianty Kamatra and Ely Kartikaningdyah, 2015) concluded that the overall performance of the company is analyzed by analyzing the financial statements. One of the analytical methods that can be used to evaluate the 
performance of a company is through financial ratio analysis. In the study, the ratio that will be used to measure financial performance is the profitability ratio.

Based on the previous illustrated literature, the author formed the following hypothesis:

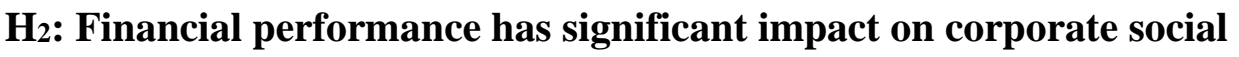
responsibility.

\section{$\underline{\text { Tax Avoidance and Firm Value }}$}

(Chen et al., 2014) investigated whether tax avoidance behavior boosts firm value in Chinese institutional setting. Several studies conduct their designs on the consumption that tax avoidance represents wealth transfer from government to enterprises and therefore promotes firm value, using the data of Chinese listed companies for the period 2001-2009 and regression model. The results demonstrated that the rise in tax avoidance tend to decrease the level of firm value.

According to (Nugroho and Agustia, 2017), the study has three objectives: First, to investigate the influence of institutional ownership, independent commissioner on tax avoidance and firm value. Second, to test the effect of tax avoidance on firm value. Third, to examine the effect of institutional ownership, independent commissioner to firm tax avoidance value as intervening variable. The sample of this study consisted of 92 manufacturing companies listed on the Indonesian Stock Exchange for the period from 2013-2016. Path analysis technique was utilized. The results of this study showed that first institutional ownership significantly influence tax avoidance. Second, independent commissioners have no effect on tax avoidance. Third, institutional ownership doesn't affect the firm value. Fourth independent commissioner and tax avoidance have significant effect to firm value. Fifth tax avoidance doesn't mediate the institutional ownership relationship to firm value.

Another study conducted by (Handayani, 2020) to determine the influence of tax avoidance and the ratio of the company's financial performance on firm value. The financial performance ratios utilized were Return on Assets (ROA), Current Ratio (CR), and Debt to Equity Ratio (DER). Cash effective tax rate was utilized to measure tax avoidance. Firm value was measured through Price Book Value (PBV). The results showed that ROA and current ratio had a positive impact on firm value, while tax avoidance and debt / equity ratio had no such influence on firm value.

Based on the previous illustrated literature, the author formed the following hypothesis:

H3: Tax avoidance has significant impact on firm value. 


\section{Corporate Social Responsibility and Firm Value}

According to (Yujing Gong et al., 2020) proponents of corporate social responsibility suggest that shareholder value can be increased through alignment with stakeholders to enhance customer loyalty and employee satisfaction and produce a favorable corporate image.

Corporate Social Responsibility based on argument of (Antonio D'Amato and Camilla Falivena, 2020) may create a good signaling effect and obtain certification for its reliability, becoming a form of accreditation for a firm that may provide superior reliability and reputation. A good reputation can attract capital, good employees, and good investors. An outstanding reputation makes the company attractive to employees who are highly qualified, giving it a competitive advantage. Moreover, increased perceived social responsibility may improve the company's reputation and allow it to exchange costly explicit claims for less expensive implicit fees. Furthermore, companies involved in corporate social responsibility activities can suffer from information asymmetry between managers and investors (Cui, Jo, Na, 2018). For instance, disclosure of corporate social responsibility gives investors more information, mitigating agency problems through corporate governance, which will be reflected in market prices.

Based on (Lopatta, Buchholz, and Kaspereit, 2016) companies with higher sustainability ratings (known as the dimensions of corporate social responsibility) are more proactive in disclosing information. Good relationships between CSR firms and their direct stakeholders (employees, customers, retailers, producers, and suppliers) can contribute to lower agency costs. According to the study of (Lin et al, 2019) corporate social responsibility includes environmental, social, and governmental activities that allow companies to echo the expectations of indirect stakeholders (social communities, charities, legislative organizations, and government) and gain their faith and trust.

Based on the previous illustrated literature, the author formed the following hypothesis:

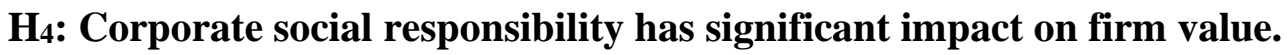




\section{Firm Value and Financial Performance}

According to (Murni et al., 2018), the study seeks to determine and investigate the effect of Capital Adequacy Ratio (CAR), Loan to Deposit Ratio (LDR), Non-Performing Loan (NPL), Debt to Equity Ratio (DER), and Return on Equity Ratio (ROE) simultaneous and partial to the banking sector in the Indonesia Stock Exchange for the period from 2010-2015. The analytical technique utilized in this study is quantitative analysis technique. The analytical tool utilized is a classical assumption test and followed by multiple linear regression analysis. The results indicated that capital adequacy ratio has a positive and significant impact on firm value, loan to deposit ratio has no significant influence on firm value. Nonperforming loan has a positive and significant influence on firm value, debt to equity ratio has negative and significant effect on firm value, and return on equity has no impact on firm value. Capital adequacy ratio, loan to deposit ratio, non-performing loan, debt to equity ratio, return on equity simultaneously have a significant effect on firm value.

According to the study conducted by( Nawaiseh,2017), the main purpose of this paper was to examine the impact of financial performance on the value of Jordanian industrial firms and test which was better to measure the financial performance, the Tobin's Q, Gross Profit/Total Assets or Operating expenses/Total Assets. The sample of the study was 40 firms during the period (2006-2015). Regression was utilized to test the study's hypotheses. In contrast to previous studies which focused on traditional performance measures, this paper takes into account the operational efficiency indicators and Tobin's Q index for computing firm's financial performance. The results study pointed out that there is a statistically significant effect of financial performance measured by Tobin's Q on firm value. In addition, there is a statistically significant effect of financial performance measured by Gross profit/total Assets on firm value. Also, there is a statistically significant effect of financial performance measured by operating expenses/total assets on firm value.

Based on the previous illustrated literature, the author formed the following hypothesis:

\section{H5: Financial performance has significant impact on firm value.}




\section{Tax Avoidance and Corporate Social Responsibility}

There are ongoing discussions based on (Prem Sikka, 2010) about the meaning and importance of "tax avoidance" and "tax evasion". In general, tax avoidance is legal and tax evasion is used to describe practices that are against the law. However, in practice, the distinction is not entirely clear. Promoters of some strategies described their plans as "avoiding," but when later examined and challenged in the courts, they turned out to be "evasive." Sometimes companies have regulated transactions that have little or no economic substance, but which enable them to reduce their tax liabilities. On moral and ethical grounds, such schemes were deemed unacceptable, especially since the loss of tax revenue has a negative impact on the provision of public goods, security, poverty alleviation and social services.

In line with current pilot business research (Roman Lanis and Grant Richardson, 2015) defines corporate tax avoidance as the regressive management of taxable income through tax planning activities. We specifically define a tax avoidance company as one that has a tax dispute involving federal, state, local, or non-U.S. Government authorities, or have been involved in a controversy over its tax obligations that have raised public concern during the period (MSCI 2012). Hence, tax avoidance may include tax planning activities that are legal or may fall into the grey area. This distinguishes tax avoidance from tax evasion which only relates to illegal activities.

According to the Principles of Responsible Investment (PRI), one of the key factors for environmental, social and institutional governance is the payment of a fair share of taxes (Principles of Responsible Investment (PRI, 2017)). In this regard, it must be noted that taxation is vital to the personality and the functioning of the state, the economy and society. Tax collection is mainly to enable the government to provide the public with all types of public goods and services. In Egypt, tax revenues represent approximately $77 \%$ of total government revenues and represent about 15.8\% of GDP (World Bank, 2017). However, tax avoidance can be seen as a valueincreasing activity by companies (Armstrong, 2015). Tax avoidance can be defined as reducing explicit taxes that are paid by companies.

There is disagreement about the relationship between corporate social responsibility and tax avoidance in the academic literature (Davis et al., 2016). Some studies dispute and find that socially responsible companies are likely to be less taxaggressive. Based on the stakeholder view, it can be said that paying taxes is a central component of corporate social responsibility practices (Lin et al., 2017). Using US data, (Lannis and Richardson, 2015) found that socially responsible firms are less likely to be involved in a major tax dispute and controversy over their tax liabilities. 
Likewise, (Hoi et al., 2013) reveal that companies with low CSR activities are more aggressive in avoiding taxes.

Based on the study of (Tarek Abdelfattah and Ahmed Aboud, 2020) he finds that in contrast, several studies indicate a positive relationship between disclosure of CSR activities and tax avoidance. Their findings are based on the arguments that a corporation is a contract between shareholders and directors, with one objective function - to maximize shareholder wealth. In such a setting, corporate social responsibility imposes a constraint, and this aspect prompts managers to make a trade-off between societal concerns and maximize shareholder wealth. Indeed, managers see lowering taxes or engaging in tax avoidance strategies beneficial to shareholders (Armstrong et al., 2015; Sikka, 2010). Meanwhile, managers expressed concern about the potential negative impacts associated with undertaking rigorous tax planning activities, such as penalties, damage to the company's reputation, public concern, and media pressure. As a result, managers tend to increase their CSR disclosure to cover up adopting tax avoidance strategies or to obtain the expected benefits from CSR reports (Hoi et al., 2013; Lin et al., 2017).

In line with the above views, Davis et al. (2016) found an alternative relationship between corporate social responsibility and tax avoidance, indicating that companies involved in tax avoidance strategies are likely to increase corporate social responsibility disclosures. These results are consistent with the legitimacy theory that companies increase ESG disclosures to alleviate community concerns about low tax payments and build legitimacy. Moreover, (Lannis and Richardson, 2013) found that an aggressive tax company increases corporate social responsibility disclosure to show that it meets societal expectations regarding its activities.

Although previous studies have examined the relationship between tax avoidance and corporate social responsibility, there is no evidence for this relationship in emerging economies, including Egypt. Similar to other developing countries, Egypt is characterized by a weak institutional position (i.e. weak enforcement systems and investor protection) and a high level of corruption (Attia, Lassoud, and Attia, 2016; Maaloul, Chakroun, and Yahyaoui, 2018). Therefore, the researcher examines the relationship between tax evasion and the level of corporate social responsibility disclosure using a dataset that includes ESG ratings.

\section{Based on the previous illustrated literature, the author formed the following hypothesis:}

H6: Tax avoidance has significant impact on corporate social responsibility. 


\section{$\underline{\text { Research Conceptual Framework }}$}

In figure (1), the researcher presents the conceptual framework for the research to show the relationships between the research independent and dependent variables and hypotheses. The left side shows the tax avoidance and the corporate social responsibility (dependent variables in hypotheses $\mathrm{H} 1$ and $\mathrm{H} 2$ and independent variables in hypotheses $\mathrm{H} 3$ and $\mathrm{H} 4$ ). The right side shows the firm value (dependent variable) and financial performance as a moderating variable.

Figure (1): Research Conceptual Framework

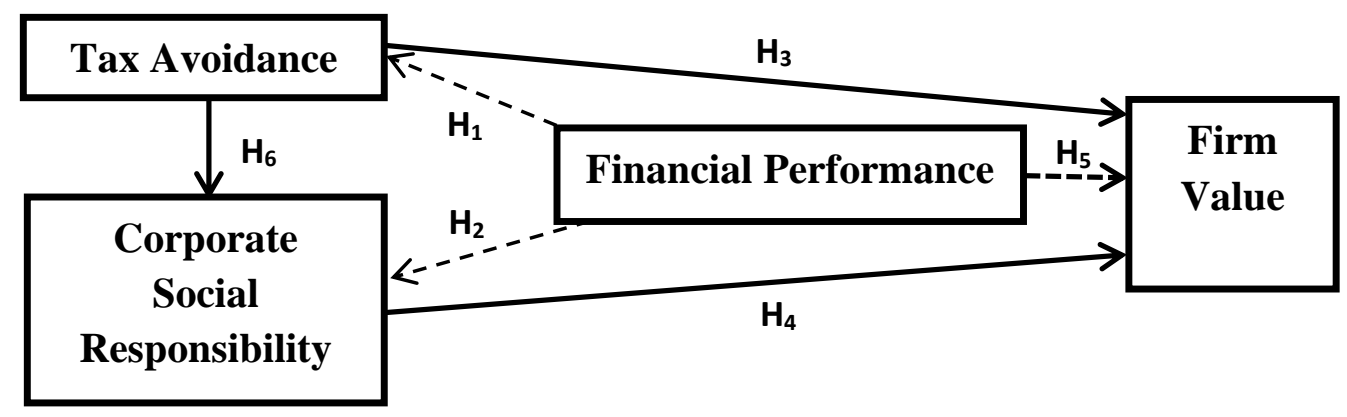

\section{$\underline{\text { Research Methodology }}$}

This research conducted using data from 36 publically listed non-financial companies listed in the Egyptian stock exchange (EGX) from the year 2012 till 2018. The researcher excludes financial firms because of their distinct financial nature. Regression equations are structured to show the relationship between the research variables and the data were obtained from the financial statements and the published annuals reports.

\section{$\underline{\text { Research Variables and Regression Model }}$}

The statistical relationship between tax avoidance, corporate social responsibility and firm value in existence of financial performance as a mediating variable was tested using the following five multiple regression models: 
First regression model, used to examine the impact of financial performance on tax avoidance

$H_{1}$ : Financial performance has significant impact on tax avoidance.

$$
\begin{gathered}
\mathbf{T A}_{\mathrm{it}}=\beta_{0}+\beta_{1} \mathbf{C R}_{\mathrm{it}}+\beta_{2} \mathbf{A T}_{\mathrm{it}}+\beta_{3} \mathrm{IT}_{\mathrm{it}}+\beta_{4} \mathbf{G P M}_{\mathrm{it}}+\beta_{5} \mathbf{R O A}_{\mathrm{it}}+\beta_{6} \mathbf{R O E}_{\mathrm{it}}+\beta_{7} \mathbf{T Q}_{\mathrm{it}}+ \\
\beta_{8} \mathrm{FS}_{\mathrm{it}}+\varepsilon_{\mathrm{it}}
\end{gathered}
$$

Where:

Dependent variable $=$ Tax Avoidance $(\mathrm{TA})$.

$\boldsymbol{\beta}_{0}=$ denotes a constant of the regression equation.

$\boldsymbol{\beta}_{1}, \boldsymbol{\beta}_{2}, \boldsymbol{\beta}_{3}, \boldsymbol{\beta}_{4}, \boldsymbol{\beta}_{5}, \boldsymbol{\beta}_{\mathbf{6}}=$ denotes regression coefficient of CR, AT, IT, GPM, ROA, ROE denotes regression coefficient of current ratio, asset turnover, inventory turnover, gross profit margin, return on assets, return on equity as measures for financial performance (liquidity, efficiency and profitability).

$\boldsymbol{\beta}_{7}$ and $\boldsymbol{\beta}_{8}=\mathrm{TQ}$ and FS denotes control variables, regression coefficient of Tobin's Q and firm size.

It $=$ Firm $\mathrm{i}$ in period $\mathrm{t}$.

$\mathbf{T}_{\mathbf{i}}=$ Year fixed effect.

$\varepsilon_{i t}=$ Standard error term.

Second regression model, used to examine the impact of financial performance on corporate social responsibility

H2: Financial performance has significant impact on corporate social responsibility.

$$
\begin{gathered}
\mathrm{CSR}_{\mathrm{it}}=\beta_{0}+\beta_{1} \mathrm{CR}_{\mathrm{it}}+\beta_{2} \mathrm{AT}_{\mathrm{it}}+\beta_{3} \mathrm{IT}_{\mathrm{it}}+\beta_{4} \mathbf{G P M}_{\mathrm{it}}+\beta_{5} \mathbf{R O A}_{\mathrm{it}}+\beta_{6} \mathrm{ROE}_{\mathrm{it}}+\beta_{7} \mathrm{TQ}_{\mathrm{it}} \\
+\beta_{8} \mathrm{FS}_{\mathrm{it}}+\varepsilon_{\mathrm{it}}
\end{gathered}
$$

Where:

Dependent variable $=$ Corporate Social Responsibility (CSR).

$\boldsymbol{\beta}_{0}=$ denotes a constant of the regression equation.

$\boldsymbol{\beta}_{1}, \boldsymbol{B}_{2}, \boldsymbol{B}_{3}, \boldsymbol{\beta}_{4}, \boldsymbol{\beta}_{5}, \boldsymbol{\beta}_{\mathbf{6}}=$ denotes regression coefficient of CR, AT, IT, GPM, ROA, ROE denotes regression coefficient of current ratio, asset turnover, inventory turnover, gross profit margin, return on assets, return on equity as measures for financial performance (liquidity, efficiency and profitability). 
$\boldsymbol{\beta}_{7}$ and $\boldsymbol{\beta}_{8}=\mathrm{TQ}$ and FS denotes control variables, regression coefficient of Tobin's Q and firm size.

It $=$ Firm $\mathrm{i}$ in period $\mathbf{t}$.

$\mathbf{T}_{\mathbf{i}}=$ Year fixed effect.

$\varepsilon_{\mathrm{it}}=$ Standard error term.

Third regression model, used to examine the relationship between tax avoidance and firm value.

H3: Tax avoidance has significant impact on firm value.

$$
\mathbf{F V}_{\mathrm{it}}=\boldsymbol{\beta}_{0}+\beta_{1} \mathrm{TA}_{\mathrm{it}}+\boldsymbol{\beta}_{2} \mathrm{TQ}_{\mathrm{it}}+\boldsymbol{\beta}_{3} \mathrm{FS}_{\mathrm{it}}+\varepsilon_{\mathrm{it}}
$$

Where:

Dependent variable $=$ Firm Value $(\mathrm{FV})$.

$\boldsymbol{\beta}_{0}=$ denotes a constant of the regression equation.

$\boldsymbol{\beta}_{1}=\mathrm{TA}$ denotes regression coefficient of tax avoidance.

$\boldsymbol{\beta}_{2}$ and $\boldsymbol{\beta}_{3}=\mathrm{TQ}$ and FS denotes control variables, regression coefficient of Tobin's Q and firm size.

It $=$ Firm $\mathrm{i}$ in period $\mathrm{t}$.

$\mathbf{T}_{\mathbf{i}}=$ Year fixed effect.

$\varepsilon_{\mathrm{it}}=$ Standard error term.

Fourth regression model, used to examine the relationship between corporate social responsibility and firm value.

$\mathrm{H}_{4}$ : Corporate social responsibility has significant impact on firm value.

$$
\mathbf{F V}_{\mathrm{it}}=\boldsymbol{\beta}_{0}+\beta_{1} \mathrm{CSR}_{\mathrm{it}}+\beta_{2} \mathrm{TQ}_{\mathrm{it}}+\beta_{3} \mathrm{FS}_{\mathrm{it}}+\varepsilon_{\mathrm{it}}
$$

Where:

Dependent variable $=$ Firm Value $(\mathrm{FV})$.

$\boldsymbol{\beta}_{0}=$ denotes a constant of the regression equation.

$\boldsymbol{\beta}_{\boldsymbol{1}}=$ CSR denotes regression coefficient of corporate social responsibility.

$\boldsymbol{\beta}_{2}$ and $\boldsymbol{\beta}_{3}=\mathrm{TQ}$ and FS denotes control variables, regression coefficient of Tobin's Q and firm size.

$\mathbf{I t}=$ Firm $\mathrm{i}$ in period $\mathbf{t}$.

$\mathbf{T}_{\mathbf{i}}=$ Year fixed effect.

$\varepsilon_{i t}=$ Standard error term. 
Fifth regression model, used to examine the relationship between financial performance and firm value.

$H_{5}$ : Financial performance has significant impact on firm value.

$$
\begin{gathered}
\mathbf{F V}_{\mathrm{it}}=\beta_{0}+\beta_{1} \mathbf{C R}_{\mathrm{it}}+\beta_{2} \mathrm{AT}_{\mathrm{it}+} \boldsymbol{\beta}_{3} \mathrm{IT}_{\mathrm{it}}+\beta_{4} \mathbf{G P M}_{\mathrm{it}}+\beta_{5} \mathbf{R O A}_{\mathrm{it}}+\beta_{6} \mathrm{ROE}_{\mathrm{it}}+\beta_{7} \mathrm{TQ}_{\mathrm{it}}+ \\
\beta_{8} \mathrm{FS}_{\mathrm{it}}+\varepsilon_{\mathrm{it}}
\end{gathered}
$$

Where:

Dependent variable $=$ Firm Value $(\mathrm{FV})$.

$\boldsymbol{\beta}_{0}=$ denotes a constant of the regression equation.

$\boldsymbol{\beta}_{1}, \boldsymbol{B}_{2}, \boldsymbol{B}_{3}, \boldsymbol{\beta}_{4}, \boldsymbol{\beta}_{5}, \boldsymbol{\beta}_{\mathbf{6}}=$ denotes regression coefficient of CR, AT, IT, GPM, ROA, ROE denotes regression coefficient of current ratio, asset turnover, inventory turnover, gross profit margin, return on assets, return on equity as measures for financial performance (liquidity, efficiency and profitability).

$\boldsymbol{\beta}_{7}$ and $\boldsymbol{\beta}_{8}=\mathrm{TQ}$ and FS denotes control variables, regression coefficient of Tobin's Q and firm size.

It $=$ Firm $\mathrm{i}$ in period $\mathrm{t}$.

$\mathbf{T}_{\mathbf{i}}=$ Year fixed effect.

$\boldsymbol{\varepsilon}_{\mathrm{it}}=$ Standard error term.

Sixth regression model, used to examine the relationship between corporate social responsibility and tax avoidance.

H6: Tax avoidance has significant impact on corporate social responsibility.

$$
\mathrm{CSR}_{\mathrm{it}}=\boldsymbol{\beta}_{0}+\boldsymbol{\beta}_{1} \mathrm{TA}_{\mathrm{it}}+\boldsymbol{\beta}_{2} \mathrm{TQ}_{\mathrm{it}}+\boldsymbol{\beta}_{3} \mathbf{F S}_{\mathrm{it}}+\varepsilon_{\mathrm{it}}
$$

Where:

Dependent variable $=$ Corporate social responsibility $(\mathrm{CSR})$.

$\boldsymbol{\beta}_{0}=$ denotes a constant of the regression equation.

$\boldsymbol{\beta}_{1}=$ TA denotes regression coefficient of tax avoidance.

$\boldsymbol{\beta}_{2}$ and $\boldsymbol{\beta}_{3}=$ TQ and FS denotes control variables, regression coefficient of Tobin's $Q$ and firm size.

It $=$ Firm $\mathrm{i}$ in period $\mathrm{t}$.

$\mathbf{T}_{\mathbf{i}}=$ Year fixed effect.

$\boldsymbol{\varepsilon}_{\mathrm{it}}=$ Standard error term. 
The measurement and definition of the research dependent and independent variables used in the regression models are listed in table (1) as follows.

Table (1): Research Variables, Definitions and Measures

\begin{tabular}{|c|c|c|}
\hline Variables & Definition & $\begin{array}{r}\text { Measure } \\
\end{array}$ \\
\hline $\begin{array}{l}\text { Tax } \\
\text { Avoidance } \\
\text { (TA) }\end{array}$ & $\begin{array}{l}\text { Tax avoidance is known as the } \\
\text { reduction in a firm's explicit tax } \\
\text { liabilities. Tax avoidance is a tax } \\
\text { planning strategies where perfectly } \\
\text { balance between legal activities and } \\
\text { aggressive activities concerning taxes. }\end{array}$ & $\begin{array}{l}\text { Effective Tax Rate (ETR) used to } \\
\text { measure tax avoidance practices. } \\
\text { ETR equal income tax expenses } \\
\text { divided by the income earned } \\
\text { before taxes. }\end{array}$ \\
\hline $\begin{array}{l}\text { Corporate } \\
\text { Social } \\
\text { Responsibility } \\
\text { (CSR) }\end{array}$ & $\begin{array}{l}\text { The most widely used definition of } \\
\text { corporate social responsibility is the one } \\
\text { proposed in } 2001 \text { by Commission of the } \\
\text { European Communities which states } \\
\text { that corporate social responsibility is "A } \\
\text { concept whereby companies incorporate } \\
\text { social and environmental concerns into } \\
\text { their business operations and in their } \\
\text { interactions with stakeholders on a } \\
\text { voluntary basis". }\end{array}$ & $\begin{array}{l}\text { The qualitative CSR data obtained } \\
\text { from the listed company financial } \\
\text { reports. } \\
\text { Using an index for CSR - through } \\
\text { use of binary values, the researcher } \\
\text { assigns the value of } 1 \text { if the } \\
\text { company is adhering to the CSR } \\
\text { framework and zero if otherwise. }\end{array}$ \\
\hline $\begin{array}{ll}\text { Firm } & \text { Value } \\
(\text { FV }) & \end{array}$ & $\begin{array}{l}\text { Firm Value (FV) is the value that a } \\
\text { business is worthy of at a particular } \\
\text { date. It refers to the market value of a } \\
\text { company. }\end{array}$ & $\begin{array}{l}\text { The firm value indicated by the } \\
\text { result of multiplying the number of } \\
\text { outstanding of shares by the } \\
\text { market share price. }\end{array}$ \\
\hline $\begin{array}{l}\text { Liquidity } \\
\text { Ratio: } \\
\text { Current Ratio } \\
\text { (CR) }\end{array}$ & $\begin{array}{l}\text { The main liquidity ratio is the current } \\
\text { ratio that indicates the company's } \\
\text { ability to settle its short-term liabilities } \\
\text { when come due within one year. }\end{array}$ & $\begin{array}{l}\text { Current ratio equal the all current } \\
\text { assets divided by all current } \\
\text { liabilities. }\end{array}$ \\
\hline $\begin{array}{l}\text { Efficiency } \\
\text { Ratio: } \\
\text { Asset } \\
\text { Turnover } \\
\text { (AT) }\end{array}$ & $\begin{array}{l}\text { Asset turnover ratio assists investors to } \\
\text { assess how companies are effectively } \\
\text { utilize their resources to generate } \\
\text { revenues. }\end{array}$ & $\begin{array}{l}\text { Asset turnover ratio equal net sales } \\
\text { revenue divided by average total } \\
\text { assets. }\end{array}$ \\
\hline $\begin{array}{l}\text { Efficiency } \\
\text { Ratio: } \\
\text { Inventory } \\
\text { Turnover (IT) }\end{array}$ & $\begin{array}{l}\text { Inventory turnover is a ratio indicates } \\
\text { on average how many times a firm sold } \\
\text { all inventory during a given period. }\end{array}$ & $\begin{array}{l}\text { Inventory turnover ratio equal the } \\
\text { cost of goods sold divided the } \\
\text { average inventory. }\end{array}$ \\
\hline $\begin{array}{l}\text { Profitability } \\
\text { Ratio: }\end{array}$ & $\begin{array}{l}\text { Gross profit margin is used by investors } \\
\text { and analysts to evaluate a }\end{array}$ & $\begin{array}{l}\text { Gross margin ratio equal the gross } \\
\text { profit of the company divided by }\end{array}$ \\
\hline
\end{tabular}




\begin{tabular}{|l|l|l|}
\hline $\begin{array}{l}\text { Gross Profit } \\
\text { Margin } \\
\text { (GPM) }\end{array}$ & firm's financial health. & net sales revenues. \\
\hline $\begin{array}{l}\text { Profitability } \\
\text { Ratio: } \\
\text { Return on } \\
\text { Assets (ROA) }\end{array}$ & $\begin{array}{l}\text { Return on assets reflects how a firm } \\
\text { effectively and efficiently utilizes its } \\
\text { available resources to generate profit. }\end{array}$ & $\begin{array}{l}\text { Return on assets ratio = Net } \\
\text { income / Total assets }\end{array}$ \\
\hline $\begin{array}{l}\text { Profitability } \\
\text { Ratio: } \\
\text { Return on } \\
\text { Equity (ROE) }\end{array}$ & $\begin{array}{l}\text { ROE ratio is used by investors to } \\
\text { evaluate how a company is good at } \\
\text { generating shareholder value. }\end{array}$ & $\begin{array}{l}\text { Return on equity ratio equal net } \\
\text { income available to common } \\
\text { stocks divided by the common } \\
\text { shareholder's equity }\end{array}$ \\
\hline $\begin{array}{l}\text { Market } \\
\text { Performance: } \\
\text { Tobin's Q } \\
\text { (TQ) }\end{array}$ & $\begin{array}{l}\text { Tobin's q measures the degree in which } \\
\text { the company generates for its } \\
\text { shareholders. It compares the book } \\
\text { value of its assets to how much more a } \\
\text { company is worth. }\end{array}$ & $\begin{array}{l}\text { Tobin's Q Market value of equity } \\
\text { Book value of short term } \\
\text { liabilities) } \div \text { Book value of total } \\
\text { assets. }\end{array}$ \\
\hline $\begin{array}{l}\text { Firm } \quad \text { Size } \\
\text { (FS) }\end{array}$ & $\begin{array}{l}\text { The total assets of the company. } \\
\text { Natural log of total assets. }\end{array}$ \\
\hline
\end{tabular}

\section{$\underline{\text { Statistical Analysis and Results }}$}

\section{Linear OLS Panel Regression Model:}

\section{Model Structure View:}

Typically, data set has a cross sectional observations among different companies and re-sampled at a certain period of time, so a balanced Panel data regression will be most applicable to represent such a linear relationship and the model equation will be written as the following:

$$
\widehat{y}_{i t}=\widehat{\beta}_{0}+\widehat{\beta}_{1} x_{1 t}+\cdots+\widehat{\beta}_{i} x_{i t}+\epsilon_{i t}
$$

\section{Where:}

- $\hat{\beta}_{\mathrm{n}}:$ The estimated constant term.

- $\hat{\beta}_{i}$ : The estimated independent Parameter coefficient.

- $y$ : The dependent variable.

- $x$ : The independent variable.

- $i$ : The Country Number.

- $t$ : Referring to the year.

- $\in$ : Model white noise error. 


\section{Steps of constructing a Panel Regression Model:}

- Set the time series variable and the cross-section variable in order to identify the panel regression model.

- Run a pooled Panel Regression and show the model significance result.

- Apply F-test to determine which more significant pooled or fixed model is.

- Apply Breusch-Pagan test to determine which is more significant Pooled or Random model is.

- Apply Hausman test to determine which is more significant Fixed or Random model is.

"In the three tests: F-test, Breusch-Pagan test, and Hausman test if the p-value $<0.05$, accept the alternative hypothesis".

Pooled OLS: The simplest estimator for panel data is pooled OLS. In most cases this is unlikely to be adequate, but it provides a baseline for comparison with more complex estimators.

Fixed Effects are constant across individuals, and random effects vary. For example, in a growth study, a model with random intercepts $a_{i}$ and fixed slope $b$ corresponds to parallel lines for different individuals, or the model $y_{i t}=a_{i}+b_{t} y_{i t}=a_{i}+b_{t}$. Kreft and De Leeuw (1998) thus distinguish between fixed and random coefficients.

- Run normality to make sure that Residuals variance is normal within your model.

- Performing the model diagnostics tests:

- White Stability test for random error variation:

The regression models and the OLS method are based on several assumptions, including the constancy of homoscedasticity by which the mean should be equal to zero, and if the Heteroscedasticity variation is used, some methods are used to overcome this problem, such as the White test. The null hypothesis is that the model has a problem of random error instability if p-value is greater than 0.05 .

- Normality of residuals:

The residuals of the forecasting model must follow the normal distribution normal distribution in the long run with mean equals zero and variance 
equals one, a Chi-square test is used for testing the normality with the criteria that if the $\mathrm{p}$-value is greater than 0.05 this means that the residuals are normally distributed.

- Ramsey RESET test for model specification:

This test is used to determine whether the model contains all the appropriate variables and excludes all irrelevant variables to ensure that the model estimated coefficients are not biased. This is done through the Ramsey RESET Test, and the decision criterion is to accept the null hypothesis that the study model includes all the appropriate variables Pvalue was greater than $(0.05)$.

- Variance Inflation Factors:

Minimum possible value $=1.0$ and the values $>10.0$ may indicate a collinearity problem.

- Goodness of fit tests:

There are many measures of accuracy and performance of the forecasts. The most commonly used measures are the mean absolute error (MAE), root mean squared error (RMSE) and mean absolute percentage error (MAPE).

- Show the graphical representation of your forecasted values within the standard error of the model.

\section{The Six Panel Models for Estimating the Six Multiple Linear Panel Regression}

\section{Equations}

After applying the pooled panel regression for the six models and performing the panel models diagnostics it's found that the most fitted linear panel model for estimating Tax Avoidance (TA) in model (1), Corporate Social Responsibility CRS in model (2) and (6), and the Firm Value in model (3) and (4) is the random effect linear panel model and the Pooled linear panel model is the most appropriate for estimating Firm Value (FV) in model (5).

The six random effect linear panel and the pooled linear panel models all showed a high level or residuals stability for long run by using white test for Heteroscedasticity and Chi-square test for normality of residuals, Also the three models independent variables and controlling variables have showed a low level of VIF which means that the they don't suffer from multicollinearity, and finally Ramsey Reset test for irrelevant variables showed that all variables are relevant 
and there is no need for adding or removing variables from any of the three models.

The following six tables (from table 2 to table 7) summarize the six linear panel models.

Table (2) shows the statistical results for the first regression model used to examine the impact of financial performance on tax avoidance.

Table (2): Random effect Linear Panel Model for Estimating Tax Avoidance

\begin{tabular}{|c|c|c|c|c|c|c|}
\hline \multirow{2}{*}{$\begin{array}{c}\text { Model } \\
\text { Independent } \\
\text { variables }\end{array}$} & \multirow{2}{*}{$\begin{array}{c}\text { Random effect } \\
\text { linear Panel }\end{array}$} & \multicolumn{2}{|c|}{$\begin{array}{c}\text { Dependent } \\
\text { variable }\end{array}$} & \multicolumn{2}{|c|}{$\boldsymbol{T A}$} & \multirow{2}{*}{ VIF Test } \\
\hline & & t-ratio & p-value & \multicolumn{2}{|c|}{ Significance } & \\
\hline constant & 0.186845 & 5.862 & $<0.0001$ & \multicolumn{2}{|c|}{ Significant } & \\
\hline $\mathrm{CR}$ & -4.549025 & -6.227 & $<0.0001$ & \multicolumn{2}{|c|}{ Significant } & 1.038 \\
\hline AT & -0.032130 & -2.687 & 0.0072 & \multicolumn{2}{|c|}{ Significant } & 1.057 \\
\hline IT & -1.6107905 & -0.2017 & 0.8401 & \multicolumn{2}{|c|}{ Insignificant } & 1.010 \\
\hline GPM & 0.0101206 & 7.9738 & $<0.0001$ & \multicolumn{2}{|c|}{ Significant } & 1.148 \\
\hline $\mathrm{ROA}$ & 0.0202272 & 3.452 & 0.0016 & \multicolumn{2}{|c|}{ Significant } & 4.459 \\
\hline $\mathrm{ROE}$ & -0.0276365 & -2.595 & 0.0095 & \multicolumn{2}{|c|}{ Significant } & 4.596 \\
\hline TQ & 3.6727705 & 2.2304 & 0.0078 & \multicolumn{2}{|c|}{ Significant } & 1.010 \\
\hline $\mathrm{FS}$ & -0.0370564 & -3.2944 & 0.0045 & \multicolumn{2}{|c|}{ Significant } & 1.065 \\
\hline \multicolumn{3}{|c|}{ Adjusted R-squared } & \multicolumn{4}{|c|}{$72.86 \%$} \\
\hline \multirow{2}{*}{\multicolumn{3}{|c|}{ Ramsey RESET overall Test }} & \multicolumn{2}{|c|}{ F-test } & \multicolumn{2}{|c|}{$\mathbf{P}$ - value } \\
\hline & & & \multicolumn{2}{|c|}{8.90696} & \multicolumn{2}{|c|}{0.082185} \\
\hline \multirow{2}{*}{\multicolumn{3}{|c|}{ Overall test of Heteroscedasticity }} & \multicolumn{2}{|c|}{ Chi-square } & \multicolumn{2}{|c|}{$\mathbf{P}$ - value } \\
\hline & & & \multicolumn{2}{|c|}{63.267580} & \multicolumn{2}{|c|}{0.029918} \\
\hline \multirow{2}{*}{\multicolumn{3}{|c|}{ Normality of Residuals }} & \multicolumn{2}{|c|}{ Chi-square } & \multicolumn{2}{|c|}{$P$ - value } \\
\hline & & & \multicolumn{2}{|c|}{115.947} & \multicolumn{2}{|c|}{0.06634} \\
\hline
\end{tabular}

Source: Prepared by the researcher.

From the previous table it is concluded that: 
- The overall Random effect model is significant with adjusted R-squared value of $72.86 \%$ which means that the significant independent variable and the controlling variables explain the change in the $T A$ by $72.86 \%$.

- All the independent variables and the controlling variables have significant impact on TA except IT should be dropped from the equation as its p-value is 0.8401 which is greater than 0.05 .

- Gross profit margin, return on assets and Tobin's Q ratio have a positive significant impact on tax avoidance, while current ratio, asset turnover, inventory turnover, return on equity and firm size have a significant negative relationship with tax avoidance.

- The overall equation for forecasting the $T A$ is:

$$
\begin{aligned}
T A_{i t}= & 0.186845-4.549025 C R_{i t}-0.032130 A T_{i t}+0.0101206 G P M_{i t} \\
& +0.0202272 R O A_{i t}-0.0276365 R O E_{i t}+3.627705 T Q_{i t} \\
& -0.0370564 F S_{i t}
\end{aligned}
$$

Table (3) shows the statistical results for the second regression model used to examine the impact of financial performance on corporate social responsibility. 
Table (3): Random Linear Panel Model for Estimating Corporate Social Responsibility

\begin{tabular}{|c|c|c|c|c|c|c|}
\hline \multirow{2}{*}{$\begin{array}{c}\text { Model } \\
\begin{array}{c}\text { Independent } \\
\text { variables }\end{array}\end{array}$} & \multirow{2}{*}{$\begin{array}{c}\begin{array}{c}\text { Random effect } \\
\text { linear Panel }\end{array} \\
\text { Coefficient }\end{array}$} & \multicolumn{2}{|c|}{$\begin{array}{c}\text { Dependent } \\
\text { variable }\end{array}$} & \multicolumn{2}{|c|}{ CSR } & \multirow{2}{*}{$\begin{array}{l}\text { VIF } \\
\text { Test }\end{array}$} \\
\hline & & t-ratio & p-value & \multicolumn{2}{|c|}{ Significance } & \\
\hline constant & 1.27169 & 1.691 & 0.0909 & \multicolumn{2}{|c|}{ Significant } & \\
\hline $\mathrm{CR}$ & 0.0887966 & 2.8485 & 0.0061 & \multicolumn{2}{|c|}{ Significant } & 1.038 \\
\hline$\overline{\mathrm{AT}}$ & -0.0141624 & -2.4481 & 0.0041 & \multicolumn{2}{|c|}{ Significant } & 1.057 \\
\hline IT & -0.0120242 & -0.5247 & 0.5998 & \multicolumn{2}{|c|}{ Insignificant } & 1.010 \\
\hline$\overline{\text { GPM }}$ & -0.00745077 & -0.2674 & 0.7892 & \multicolumn{2}{|c|}{ Insignificant } & 1.148 \\
\hline$\overline{\mathrm{ROA}}$ & -0.0659450 & -1.695 & 0.0400 & \multicolumn{2}{|c|}{ Significant } & 4.459 \\
\hline $\mathrm{ROE}$ & 0.0783611 & 2.600 & 0.0093 & \multicolumn{2}{|c|}{ Significant } & 4.596 \\
\hline TQ & -0.0114566 & -2.556 & 0.0106 & \multicolumn{2}{|c|}{ Significant } & 1.010 \\
\hline$\overline{F S}$ & -0.0202298 & -6.7258 & $<0.0001$ & \multicolumn{2}{|c|}{ Significant } & 1.065 \\
\hline \multicolumn{3}{|c|}{ Adjusted R-squared } & \multicolumn{4}{|c|}{$46.15 \%$} \\
\hline \multirow{2}{*}{\multicolumn{3}{|c|}{ Ramsey RESET overall Test }} & \multicolumn{2}{|c|}{ F-test } & \multicolumn{2}{|c|}{$P$ - value } \\
\hline & & & \multicolumn{2}{|c|}{11.906961} & \multicolumn{2}{|c|}{0.09963862} \\
\hline \multirow{2}{*}{\multicolumn{3}{|c|}{ Overall test of Heteroscedasticity }} & \multicolumn{2}{|c|}{ Chi-square } & \multicolumn{2}{|c|}{$P$ - value } \\
\hline & & & \multicolumn{2}{|c|}{41.854324} & \multicolumn{2}{|c|}{0.004002} \\
\hline \multirow{2}{*}{\multicolumn{3}{|c|}{ Normality of Residuals }} & \multicolumn{2}{|c|}{ Chi-square } & \multicolumn{2}{|c|}{$P$ - value } \\
\hline & & & \multicolumn{2}{|c|}{267.623} & \multicolumn{2}{|c|}{0.11234} \\
\hline
\end{tabular}

Source: Prepared by the researcher.

\section{From the previous table it is concluded that:}

- The overall random effect model is significant with adjusted $\mathrm{R}$-squared value of $46.15 \%$ which means that the significant independent variable and the controlling variables explain the change in the CSR by $46.15 \%$.

- All the independent variables and the controlling variables have significant impact on CSR except IT and GPM should be dropped from the equation as their p-value are 0.5998 and 0.7892 respectively which are greater than 0.05 .

- Current ratio and return on equity have a positive significant impact on corporate social responsibility, while asset turnover, return on assets, Tobin's 
$\mathrm{Q}$ ratio and firm size have a significant negative relationship with corporate social responsibility.

- The overall equation for forecasting the CSR is:

$$
\begin{gathered}
C S R_{i t}=1.27169+0.0887966 \mathrm{CR}_{i t}-0.0141624 A T_{i t}-0.0659450 R O A_{i t} \\
+0.0783611 R O E_{i t}-0.0114566 T Q_{i t}-0.0202298 F S_{i t}
\end{gathered}
$$

Table (4) shows the statistical results for the third regression model used to examine the relationship between tax avoidance and firm value.

\begin{tabular}{|c|c|c|c|c|c|c|}
\hline Model & $\begin{array}{c}\text { Random effect } \\
\text { linear Panel }\end{array}$ & \multicolumn{2}{|c|}{$\begin{array}{c}\text { Dependent } \\
\text { variable }\end{array}$} & \multicolumn{2}{|c|}{$\boldsymbol{F V}$} & \multirow{2}{*}{ VIF Test } \\
\hline $\begin{array}{c}\text { Independent } \\
\text { variables }\end{array}$ & Coefficient & t-ratio & p-value & \multicolumn{2}{|c|}{ Significance } & \\
\hline constant & 11.8649 & 2.851 & 0.0044 & \multicolumn{2}{|c|}{ Significant } & \\
\hline TA & 14.6850 & 1.847 & 0.0447 & \multicolumn{2}{|c|}{ Significant } & 1.006 \\
\hline TQ & 0.0271083 & 2.349 & 0.0073 & \multicolumn{2}{|c|}{ Significant } & 1.005 \\
\hline FS & 0.0803969 & 2.4420 & 0.0085 & \multicolumn{2}{|c|}{ Significant } & 1.011 \\
\hline \multicolumn{3}{|c|}{ Adjusted R-squared } & \multicolumn{4}{|c|}{$69.41 \%$} \\
\hline \multirow{2}{*}{\multicolumn{3}{|c|}{ Ramsey RESET overall Test }} & \multicolumn{2}{|c|}{ F-test } & \multicolumn{2}{|c|}{$\mathbf{P}$ - value } \\
\hline & & & \multicolumn{2}{|c|}{0.1136338} & \multicolumn{2}{|c|}{0.893} \\
\hline \multirow{2}{*}{\multicolumn{3}{|c|}{ Overall test of Heteroscedasticity }} & \multicolumn{2}{|c|}{ Chi-square } & \multicolumn{2}{|c|}{$\mathbf{P}$ - value } \\
\hline & & & \multicolumn{2}{|c|}{0.053061} & \multicolumn{2}{|c|}{0.046505} \\
\hline \multirow{2}{*}{\multicolumn{3}{|c|}{ Normality of Residuals }} & \multicolumn{2}{|c|}{ Chi-square } & \multicolumn{2}{|c|}{$P$ - value } \\
\hline & & & \multicolumn{2}{|c|}{17.666} & \multicolumn{2}{|c|}{0.05015} \\
\hline
\end{tabular}

Table (4): Random Linear Panel Model for Estimating Firm Value

Source: Prepared by the researcher.

From the previous table it is concluded that:

- The overall random effect model is significant with adjusted R-squared value of $69.41 \%$ which means that the significant independent variable and the controlling variables explain the change in the $F V$ by $69.41 \%$.

- All the independent variables and the controlling variables have significant impact on FV. 
- Tax avoidance, Tobin's Q ratio and firm size have a positive significant impact on firm value.

- The overall equation for forecasting the $F V$ is:

$$
F V_{i t}=11.8649+14.6850 T A_{i t}+0.0271083 T Q_{i t}+0.0803969 F S_{i t}
$$

Table (5) shows the statistical results for the fourth regression model used to examine the relationship between corporate social responsibility and firm value.

Table (5): Random Linear Panel Model for Estimating Firm Value

\begin{tabular}{|c|c|c|c|c|c|c|}
\hline \multirow{2}{*}{$\begin{array}{c}\text { Model } \\
\begin{array}{c}\text { Independent } \\
\text { variables }\end{array}\end{array}$} & \multirow{2}{*}{\begin{tabular}{|c}
$\begin{array}{c}\text { Random effect } \\
\text { linear Panel }\end{array}$ \\
Coefficient
\end{tabular}} & \multicolumn{2}{|c|}{$\begin{array}{c}\text { Dependent } \\
\text { variable }\end{array}$} & \multicolumn{2}{|c|}{$F V$} & \multirow{2}{*}{ VIF Test } \\
\hline & & t-ratio & $p$-value & \multicolumn{2}{|c|}{ Significance } & \\
\hline constant & 11.3145 & 2.700 & 0.0069 & \multicolumn{2}{|c|}{ Significant } & \\
\hline CSR & 0.0158057 & 3.5574 & 0.0055 & \multicolumn{2}{|c|}{ Significant } & 1.022 \\
\hline TQ & 15.0394 & 3.868 & 0.0018 & \multicolumn{2}{|c|}{ Significant } & 1.005 \\
\hline FS & 0.107016 & 2.590 & 0.0450 & \multicolumn{2}{|c|}{ Significant } & 1.011 \\
\hline \multicolumn{3}{|c|}{ Adjusted R-squared } & \multicolumn{4}{|c|}{$59.41 \%$} \\
\hline \multirow{2}{*}{\multicolumn{3}{|c|}{ Ramsey RESET overall Test }} & \multicolumn{2}{|c|}{ F-test } & \multicolumn{2}{|c|}{$P$ - value } \\
\hline & & & \multicolumn{2}{|c|}{0.116325} & \multicolumn{2}{|c|}{0.887} \\
\hline \multirow{2}{*}{\multicolumn{3}{|c|}{ Overall test of Heteroscedasticity }} & \multicolumn{2}{|c|}{ Chi-square } & \multicolumn{2}{|c|}{$P$ - value } \\
\hline & & & \multicolumn{2}{|c|}{10.527767} & \multicolumn{2}{|c|}{0.029918} \\
\hline \multirow{2}{*}{\multicolumn{3}{|c|}{ Normality of Residuals }} & \multicolumn{2}{|c|}{ Chi-square } & \multicolumn{2}{|c|}{$P$ - value } \\
\hline & & & \multicolumn{2}{|c|}{17.988} & \multicolumn{2}{|c|}{0.06012} \\
\hline
\end{tabular}

Source: Prepared by the researcher.

From the previous table it is concluded that:

- The overall random effect model is significant with adjusted R-squared value of $59.41 \%$ which means that the significant independent variable and the controlling variables explain the change in the $F V$ by $59.41 \%$.

- All the independent variables and the controlling variables have significant impact on FV. 
- Corporate social responsibility, Tobin's Q ratio and firm size have a positive significant impact on firm value.

- The overall equation for forecasting the $F V$ is:

$$
F V_{i t}=11.3145+0.0158057 \operatorname{CSR}_{i t}+15.0394 T Q_{i t}+00.107016 F S_{i t}
$$

Table (6) shows the statistical results for the fifth regression model used to examine the relationship between financial performance and firm value.

Table (6): Random Linear Panel Model for Estimating Firm Value

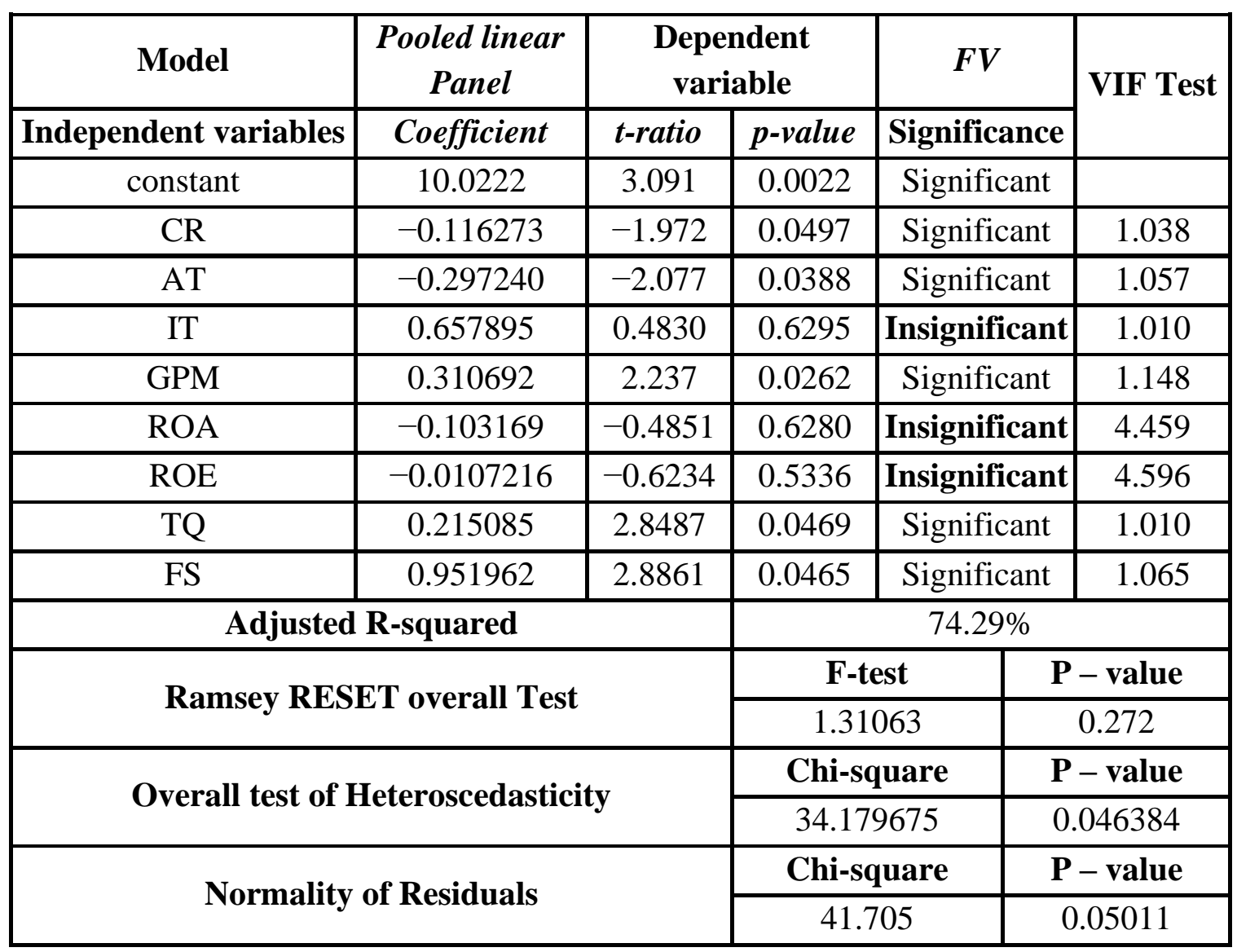

Source: Prepared by the researcher. 


\section{From the previous table it is concluded that:}

- The overall Pooled linear model is significant with adjusted R-squared value of $74.29 \%$ which means that the significant independent variable and the controlling variables explain the change in the $F V$ by $74.29 \%$.

- All the independent variables and the controlling variables have significant impact on FV except IT, ROA and ROE should be dropped from the equation as their $p$-value are $0.6295,0.6280$ and 0.5336 respectively which are greater than 0.05 .

- Gross profit margin, Tobin's Q ratio and firm size have a positive significant impact on firm value, while current ratio and asset turnover have a significant negative relationship with firm value.

- The overall equation for forecasting the $F V$ is:

$$
\begin{gathered}
F V_{i t}=10.0222-0.116273 C R_{i t}-0.297240 A T_{i t}+0.310692 G P M_{i t} \\
+0.215085 T Q_{i t}+0.951962 F S_{i t}
\end{gathered}
$$

Table (7) shows the statistical results for the sixth regression model used to examine the relationship between tax avoidance and corporate social responsibility. 
Table (7): Random Linear Panel Model for Estimating Corporate Social Responsibility

\begin{tabular}{|c|c|c|c|c|c|c|}
\hline \multirow{2}{*}{$\begin{array}{c}\text { Model } \\
\begin{array}{c}\text { Independent } \\
\text { variables }\end{array}\end{array}$} & \multirow{2}{*}{\begin{tabular}{|c} 
Random effect \\
linear Panel
\end{tabular}} & \multicolumn{2}{|c|}{$\begin{array}{c}\text { Dependent } \\
\text { variable }\end{array}$} & \multicolumn{2}{|c|}{ CSR } & \multirow{2}{*}{ VIF Test } \\
\hline & & t-ratio & $p$-value & \multicolumn{2}{|c|}{ Significance } & \\
\hline constant & 11.8649 & 2.851 & 0.0044 & \multicolumn{2}{|c|}{ Significant } & \\
\hline TA & 14.6850 & 1.847 & 0.0447 & \multicolumn{2}{|c|}{ Significant } & 1.006 \\
\hline$\overline{\mathrm{TQ}}$ & 0.0271083 & 2.349 & 0.0073 & \multicolumn{2}{|c|}{ Significant } & 1.005 \\
\hline$\overline{F S}$ & 0.0803969 & 2.4420 & 0.0085 & \multicolumn{2}{|c|}{ Significant } & 1.011 \\
\hline \multicolumn{3}{|c|}{ Adjusted R-squared } & \multicolumn{4}{|c|}{$46.15 \%$} \\
\hline \multirow{2}{*}{\multicolumn{3}{|c|}{ Ramsey RESET overall Test }} & \multicolumn{2}{|c|}{ F-test } & \multicolumn{2}{|c|}{$\mathbf{P}$ - value } \\
\hline & & & 0.113 & & \multicolumn{2}{|c|}{0.893} \\
\hline \multirow{2}{*}{\multicolumn{3}{|c|}{ Overall test of Heteroscedasticity }} & \multicolumn{2}{|c|}{ Chi-square } & & - value \\
\hline & & & \multirow{2}{*}{\multicolumn{2}{|c|}{ Chi-square }} & \multicolumn{2}{|c|}{0.046505} \\
\hline \multirow{2}{*}{\multicolumn{3}{|c|}{ Normality of Residuals }} & & & & - value \\
\hline & & & \multicolumn{2}{|c|}{271.932} & \multicolumn{2}{|c|}{0.056621} \\
\hline
\end{tabular}

Source: Prepared by the researcher.

\section{From the previous table it is concluded that:}

- The overall random effect model is significant with adjusted R-squared value of $46.15 \%$ which means that the significant independent variable and the controlling variables explain the change in the CSR by $46.15 \%$.

- All the independent variables and the controlling variables have significant impact on CSR except FS has a p-value of 0.3308 which is greater than 0.05 .

- Tax avoidance and Tobin's Q ratio have a significant negative relationship with corporate social responsibility.

- The overall equation for forecasting the $\operatorname{CSR}$ is:

$$
C S R_{i t}=1.93390-3.49213 T A_{i t}-0.0116331 T Q_{i t}
$$


Figure (2), presents the forecasting charts of the tax avoidance, corporate social responsibility and firm value in the six models for the entire time series period from 2012 till 2018 for the 36 cross section company of sample.

\section{Figure (2): The Forecasting Charts of the Six Linear Panel Models}

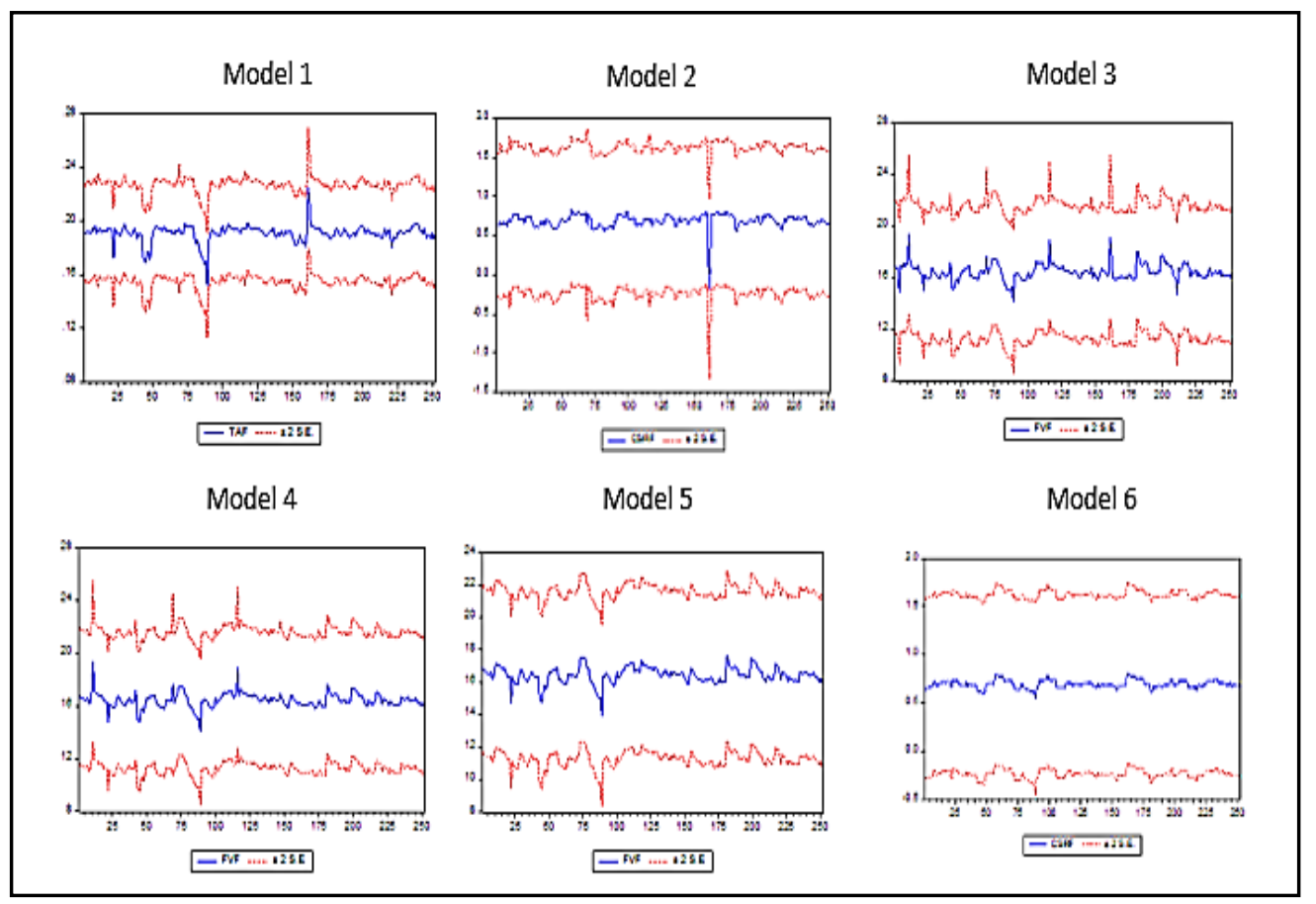

Source: E-views software.

Table (8) summarizes the results of the six linear panel regression models and their hypotheses. 
Table (8): Summary Table.

\begin{tabular}{|c|c|c|c|c|c|c|}
\hline \multicolumn{7}{|c|}{ Model } \\
\hline \multirow{4}{*}{$\begin{array}{c}\text { Overall } \\
\text { Hypothesis }\end{array}$} & \multicolumn{2}{|r|}{ First } & \multicolumn{2}{|c|}{ Second } & \multicolumn{2}{|c|}{ Third } \\
\hline & Type & Significance & Type & Significance & Type & Significance \\
\hline & \multicolumn{2}{|c|}{ Accept The Hypothesis } & \multicolumn{2}{|c|}{ Accept The Hypothesis } & \multicolumn{2}{|c|}{ Accept The Hypothesis } \\
\hline & \multicolumn{2}{|c|}{$\begin{array}{c}\text { Significant Relationship } \\
\text { exists }\end{array}$} & \multicolumn{2}{|c|}{$\begin{array}{c}\text { Significant Relationship } \\
\text { exists }\end{array}$} & \multicolumn{2}{|c|}{$\begin{array}{c}\text { Significant Relationship } \\
\text { exists }\end{array}$} \\
\hline $\begin{array}{c}\text { Sub } \\
\text { Hypothesis }\end{array}$ & \multicolumn{2}{|c|}{$\begin{array}{c}\text { Accept } \mathbf{H}_{\mathbf{1}} \text { : Financial } \\
\text { performance has } \\
\text { significant impact on tax } \\
\text { avoidance. }\end{array}$} & \multicolumn{2}{|c|}{$\begin{array}{l}\text { Accept } \mathbf{H}_{2} \text { : Financial } \\
\text { performance has } \\
\text { significant impact on } \\
\text { corporate social } \\
\text { responsibility. }\end{array}$} & \multicolumn{2}{|c|}{$\begin{array}{l}\text { Accept } \mathbf{H}_{3} \text { : Tax avoidance } \\
\text { has significant impact on } \\
\text { firm value. }\end{array}$} \\
\hline \multirow{4}{*}{$\begin{array}{c}\text { Overall } \\
\text { Hypothesis }\end{array}$} & \multicolumn{2}{|r|}{ Forth } & \multicolumn{2}{|r|}{ Fifth } & \multicolumn{2}{|r|}{ Six } \\
\hline & Type & Significance & Type & Significance & Type & Significance \\
\hline & \multicolumn{2}{|c|}{ Accept The Hypothesis } & \multicolumn{2}{|c|}{ Accept The Hypothesis } & \multicolumn{2}{|c|}{ Accept The Hypothesis } \\
\hline & \multicolumn{2}{|c|}{$\begin{array}{c}\text { Significant Relationship } \\
\text { exists }\end{array}$} & \multicolumn{2}{|c|}{$\begin{array}{c}\text { Significant Relationship } \\
\text { exists }\end{array}$} & \multicolumn{2}{|c|}{$\begin{array}{c}\text { Significant Relationship } \\
\text { exists }\end{array}$} \\
\hline $\begin{array}{c}\text { Sub } \\
\text { Hypothesis }\end{array}$ & \multicolumn{2}{|c|}{$\begin{array}{c}\text { Accept } \mathbf{H}_{4} \text { : Corporate } \\
\text { social responsibility has } \\
\text { significant impact on firm } \\
\text { value. }\end{array}$} & \multicolumn{2}{|c|}{$\begin{array}{c}\text { Accept } \mathbf{H}_{5} \text { : Financial } \\
\text { performance has } \\
\text { significant impact on firm } \\
\text { value. }\end{array}$} & \multicolumn{2}{|c|}{$\begin{array}{l}\text { Accept } \mathbf{H}_{6} \text { : Tax avoidance } \\
\text { has significant impact on } \\
\text { corporate social } \\
\text { responsibility. }\end{array}$} \\
\hline
\end{tabular}

Source: Prepared by the researcher.

\section{Conclusion}

This research investigates the how tax avoidance and corporate social responsibility affect the value of firm in the Egyptian Listed Companies using financial performance as a mediating variable. Using a research sample of 36 nonfinancial listed firms during the period 2012-2018, the researcher run six multiple regression models to examine the impact of tax avoidance and corporate social responsibility, Tobin's $Q$ ratio and firm size on firm value using the financial performance as a moderator variable (measured using margin, current ratio, asset turnover, inventory turnover, profit gross margin, ROE, ROA). The statistical results found that gross profit margin, return on assets and Tobin's $\mathrm{Q}$ ratio have a positive significant impact on tax avoidance, while current ratio, asset turnover, inventory turnover, return on equity and firm size have a significant negative relationship with 
tax avoidance. In addition findings shows that current ratio and return on equity have a positive significant impact on corporate social responsibility, while asset turnover, return on assets, Tobin's Q ratio and firm size have a significant negative relationship with corporate social responsibility.

Moreover, tax avoidance, corporate responsibility social, Tobin's Q ratio and firm size found to have a positive significant impact on firm value.

Also, research results indicates that gross profit margin, Tobin's Q ratio and firm size have a positive significant impact on firm value, while current ratio and asset turnover have a significant negative relationship with firm value. In meantime, tax avoidance and Tobin's Q ratio have a significant negative relationship with corporate social responsibility.

\section{References}

1.

Antonio D'Amato and Camilla Falivena (2020). "Corporate Social Responsibility and Firm Value: Do Firm Size and Age Matter? Empirical Evidence from European Listed Companies". Corporate Social Responsibility and Environmental Management, Vol. 27, pp. 909-924.

2. Armstrong, C. S., Blouin, J. L., Jagolinzer, A. D., and Larcker, D. F. (2015). "Corporate Governance, Incentives, and Tax Avoidance". Journal of Accounting and Economics, Vol. 60, No.1, pp.1-17.

3.

Attia, M., Lassoued, N., and Attia, A. (2016). "Political Costs and Earnings Management: Evidence from Tunisia". Journal of Accounting in Emerging Economies, Vol. 6, No. 4, pp. 388-407.

4.

Bidhari, S.C., Salim, U., Aisjah, S. (2013), "Effect of Corporate Social Responsibility Information Disclosure on Financial Performance and Firm Value in Banking Industry Listed at Indonesia Stock Exchange". European Journal of Business and Management, Vol. 5, pp. 39-46.

5. Chen,X., Hu,N. and Wang,X., 2014. "Tax Avoidance and Firm Value: Evidence from China". Nankai Business Review International, Vol. 5, No. 1, pp. 25-42.

6.

Cui, J., Jo, H., and Na, H. (2018). "Does Corporate Social Responsibility affect Information Asymmetry?'. Journal of Business Ethics, Vol. 148, No.3, pp. 549-572. 
7.

Dahlsrud (2008). "How

Corporate Social Responsibility is Defined: an Analysis of 37 Definitions". Corporate Social Responsibility and Environmental Management, Vol. 15, No. 1, pp. 1-13.

8.

Davis, A. K., Guenther,

D. A., Krull, L. K., and Williams, B. M. (2016). "Do Socially Responsible Firms Pay More Taxes?”. The Accounting Review, Vol. 91, No. 1, pp. 47-68.

9. Desai, M.A., and Dharmapala, D., (2009). "Corporate Tax Avoidance and Firm Value. The Review of Economics and Statistics, Vol. 91, No. 3, pp. 537-546.

10 .

Duhigg, C., and Kocieniewski, D. (2012). "How apple sidesteps billions in taxes". New York Times. Avaliable at: http://www.nytimes.com/2012/04/29/ business/apples-tax-strategy-aims-at-lowtax-states-and-nations.html?pagewanted=all.

11. Dyreng, S.D., Hanlon, M. and Maydew, E.L. (2008). "Long-run Corporate Tax Avoidance". The Accounting Review, Vol. 83, No.1, pp. 61-82.

12. Handayani, R, (2020). "Effects of Tax Avoidance and Financial Performance on Firm Value". International Journal of Management Studies and Social Science Research, Vol. 2, No.5, pp. 159-168.

13. Hanlon, M. and Heitzman, S., (2010). "A Review of Tax Research". Journal of Accounting and Economics, Vol. 50, No. 2/3, pp.127-178.

14.

Hasseldine, J., and Morris, G. (2013). "Corporate Social Responsibility and Tax Avoidance: A Comment and Reflection”. Accounting Forum, Vol. 37, No.1, pp. 1-14.

15.

Hoi, C. K., Wu, Q., and Zhang, H. (2013). "Is Corporate Social Responsibility (CSR) Associated with Tax Avoidance? Evidence from Irresponsible CSR Activities". The Accounting Review, Vol. 88, No. 6, pp. 2025-2059.

16

Kusumadilaga, R. (2010). "Against the Influence of Corporate Social Responsibility Corporate Values with Profitability as Moderating Variables". Semarang: Faculty of Economics, University of Diponegoro.

17. Lee, B.B., Dobiyanski, A., and Minton, S., (2015). "Theories and Empirical Proxies for Corporate Tax Avoidance". The Journal of Applied Business and Economics, Vol.17, No.3, pp. 21-34.

18.

Lin et al, (2019).

"Financial Performance and Corporate Social Responsibility: Empirical Evidence from Taiwan”. Asia Pacific Management Review, Vol. 24, pp. 61-71. 
19.

Lopatta, K., Buchholz,

F., and Kaspereit, T. (2016). "Asymmetric Information and Corporate Social Responsibility”. Business Society, Vol. 5, No. 3, pp. 458-488.

20.

Maaloul, A., Chakroun, R., and Yahyaoui, S. (2018). "The Effect of Political Connections on Companies' Performance and Value: Evidence from Tunisian companies after the revolution". Journal of Accounting in Emerging Economies, Vol. 8, No.2, pp. 185-204.

21.

MSCI.

(2012).

Environmental, social and governance. Avaliable at: http://www. msci.com/products/esg/stats/

22.

Murni,S., (2018). "The

Role of Financial Performance in Determining the Firm Value". Advances in Economics, Business and Management Research, Vol. 73, pp. 66-70.

23. Nawaiseh, M., (2017). "The Impact of the Financial Performance on Firm Value:

Evidence from Developing Countries. International Journal of Applied Business and Economic Research, Vol.15, No.16, pp. 329-341.

24.

Novrianty Kamatra and Ely Kartikaningdyah (2015). "Effect

Corporate Social Responsibility on Financial Performance". International Journal of Economics and Financial Issues, Vol.5 (Special Issue), pp. 157-164.

25. Nugroho, W.C. and Agustia, D., (2017). "Corporate Governance, Tax Avoidance, and Firm Value". AFEBI Accounting Review, Vol. 2, No. 2, pp. 15-29.

26.

Porter, M. E., and

Kramer, M. R. (2006). "Strategy and Society: The Link between Competitive Advantage and Corporate Social Responsibility". Harvard Business Review, Vol. 84, No. 12, pp. 78-92.

27.

Prem Sikka (2010).

"Smoke and Mirrors: Corporate Social Responsibility and Tax Avoidance". Accounting Forum, Vol. 34, pp. 153-168.

28.

Resturiyani, N. (2012).

"Influence of Corporate Social Responsibility Disclosure of Financial Performance (Study on Mining Company Listed in Indonesia Stock Exchange in 2011)". Bandung: Faculty of Economics Universtas Pasundan.

29.

Roman Lanis and Grant

Richardson (2015). "Is Corporate Social Responsibility Performance Associated with Tax Avoidance?'. Journal of Business Ethics, Vol. 127, pp. 439-457.

30 .

Santa, S. L. L., (2016).

"Corporate Tax avoidance and Firm Value: From Brazil". Revista 
Contemporânea de Contabilidade, Vol. 13, No. 30, pp. 114-133. Available at: https://doi.org/10.5007/2175-8069.2016v13n30p114.

31.

Tarek Abdelfattah and

Ahmed Aboud (2020). "Tax Avoidance, Corporate Governance, and Corporate Social Responsibility: The Case of the Egyptian Capital Market". Journal of International Accounting, Auditing and Taxation, Vol. 38, pp. 1-16.

32. Vicente Lima Criso'stomo, Fa'tima de Souza Freire and Felipe Cortes de Vasconcellos, (2011). "Corporate Social Responsibility, Firm Value and Financial Performance in Brazil", Social Responsibility Journal, Vol. 7, No. 2, pp. 295-309.

33. Wiratmoko,S, (2018). "The Effect of Corporate Governance, Corporate Social Responsibility and Financial Performance on Tax Avoidance". The Indonesian Accounting Review, Vol. 8, No. 2, pp. 245-257.

34. Yaparto, M., Frisko, K.D., Eriandani, R. (2013). "Influence of Corporate Social Responsibility Financial Performance Against SektorManufaktur Registered In Indonesia Stock Exchange Period 2010-2011". Student Scientific Journal Universitas Surabaya, Vol. 2, No. 1, pp. 1-19.

35. Yee, C. S., Sapiei, N. S., and Abdullah, M., (2018). "Tax Avoidance, Corporate Governance and Firm Value in the Digital Era". Journal of Accounting and Investment, Vol. 19, No. 2, pp. 159-175. Available at: https://doi.org/10.18196/jai.190299.

36. Yujing Gong, Cheng Yan, Kung-Cheng Ho (2020). "The Effect of Managerial Ability on Corporate Social Responsibility and Firm Value in the Energy Industry'. Corporate Social Responsibility and Environmental Management, Vol. 11, pp. 1-14. 